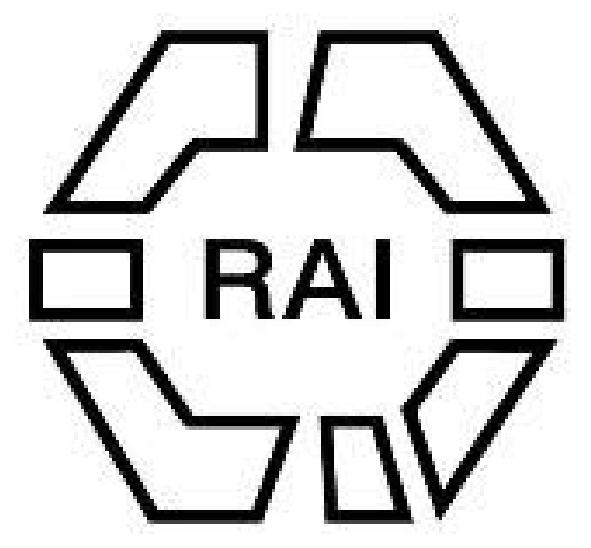

\title{
WILEY
}

\section{Note on the Gogodara (Kabiri or Girara.)}

\author{
Author(s): A. C. Haddon
}

Source: Man, Vol. 17 (Dec., 1917), pp. 193-194

Published by: Royal Anthropological Institute of Great Britain and Ireland

Stable URL: http://www.jstor.org/stable/2788020

Accessed: 26-06-2016 19:20 UTC

Your use of the JSTOR archive indicates your acceptance of the Terms \& Conditions of Use, available at

http://about.jstor.org/terms

JSTOR is a not-for-profit service that helps scholars, researchers, and students discover, use, and build upon a wide range of content in a trusted digital archive. We use information technology and tools to increase productivity and facilitate new forms of scholarship. For more information about JSTOR, please contact support@jstor.org.

Royal Anthropological Institute of Great Britain and Ireland, Wiley are collaborating with JSTOR to digitize, preserve and extend access to Man 
sometimes called, are all appointed annually by the cacique, by "his brothers and uncles." To the principales the tenientes would refer any important question. The people have four ceremonial hunts a year for the cacique and they bring in his harvest. In the allotment of farm lands he has complete say, or rather not he but his "brothers and uncles." In the words of my Acoma informant, "the cacique " himself does not go round, he knows nothing about the people; it is his brothers " and uncles who find out for him and tell him what to do"-clan autocracy indeed.

ELSIE CLEWS PARSONS.

Ethnography.

Haddon.

Note on the Gogodara (Kabiri or Girara.) By Dr. A. C. Haddon.

I much regret that in my paper on these people (Journ. Roy. Anthr.

Inst., XLVI, 1916, p. 334) I omitted to refer to a paper entitled "A Description of the Girara District, Western Papua," by W. N. Beaver, in The Geographical Journal, XLIII, 1914, p. 407. The greater part of this communication consists in an excellent account of the physical character of the country travelled over by Mr. Beaver, with a short list of the characteristic animals inhabiting it. In order to render my account of the people as complete as possible, I now give briefly all the additional ethnographical data supplied by Mr. Beaver : He says : "I am not prepared to offer " any theories as to the racial origin of the Girara people; but it is certain that " their language is Papuan, not Melanesian nor Papuo-Melanesian. The people " themselves say that not far from Gaima [a village on the Fly river], a man " married a dog, and had as offspring three sons, the two elder of whom settled at "Domori [an island in the Fly river] and Pagona [an adjacent riverain village], " and were the ancestors of the people of those places, whereas the youngest, having " quarrelled with his elder brothers, went inland, where he saw that the country " was good, and decided to make a village. In spite of their dog ancestry, this " animal, as far as I am aware, is not the totem of any of them, their totems being " five in number: the pig (Itira), the pigeon (Boboa-I think this is the Goura “ pigeon), the alligator [crocodile] (Dupa), the cassowary (Goragora), and the snake “ (Amura). The totems were first given out to the people by a hero-ancestor called " Ibari. The totem customs do not differ materially from those of other western " tribes, and are patrilinear." The crocodile and the pig seem to figure largely in the tribal life of the people, well-carved representations of the former appearing on the canoe prows, and of the latter on the house steps.

The people are of medium sturdy stature, and seem tolerably healthy, although skin disease ('Tinea imbricata), yaws, and a good deal of elephantiasis occur. The hair is shaved back, showing a high narrow forehead, and a small corkscrew goatee beard (ene) is worn. Mr. Beaver refers to the conical fibre hats decorated with feathers worn by most of the men, while others wear skull caps of network. The women cover the head, face, and bosom with a veil of net, which is stated to be a mourning dress. The other dress is scanty, and consists of a long tail of coloured grass woven on to a plaited cane belt, drawn tightly between the legs and tucked in the belt again behind. Neither sex tattoo, but cicatrices are in some instances raised.

"The chiefs have a little authority. The late chief of Barimo [the central village of the district], combining the dual functions of chief and sorcerer, was, as far as I saw, the one man in the west implicitly obeyed by his people. A chief is succeeded by his brother, not his son, and the son succeeds after the death of his uncle. Polygamy is the rule, the number of wives occasionally being 14 or 15 . Divorce is uncommon."

Mr. Beaver has seen women's houses as well as the large communal house, of [ 193 ] 
which each village usually consists. The central part of the house, which is from $4 \cdot 58-6 \cdot 1 \mathrm{~m}$. (15-20 ft.) wide or more, is allotted solely to the men, as are also the doors at each end. The only occasion on which women use these doors is during the ceremony attending the dedication of a new house. At each side of the central space are tiers of cubicles, two deep and two or three high. These are approached by ladders, and are used by the women and children, having entrances from the side. The dimensions of the Dogona house are $152.5 \mathrm{~m}$. (500 ft.) by $35.68 \mathrm{~m}$. (117 ft.), and $21 \cdot 35 \mathrm{~m}$. (70 ft.) high.

Sago and fish are roasted in sago leaves or in canes, and, with coconuts, form the staple diet. There are huge fields of sago and coconuts wherever it is possible to plant. Other vegetables used as food are taro and yams. Sweet potatoes and bananas are not largely cultivated, chiefly because the area of suitable land is not very great. They are planted in beds, and protected from the sun with shade sheds, as are sprouting coconuts; "the intelligence of these people in their methods of agriculture " is, indeed, of a high order. T.hey are head hunters, but not cannibals. Betel nut " mixed with lime is chewed day and night with something almost approaching " ceremonial. The lime is obtained from the coast, to which trading expeditions are " made to buy shells for the purpose of burning. . . . The women are expert at " fishing. They use either a net on a cane frame, something like a butterfly net, " or else a large trap made of black cane, looking very like a lobster pot. 'These " traps are from 5 to $7 \mathrm{ft}$. high $[1 \cdot 524-2 \cdot 135 \mathrm{~m}$.$] . . . . The yellow cuscus and$ " small flying phalanger are often kept as pets. . . . Very fine tobacco is grown " by the natives and put up in rolls; this is traded principally with Domori and " the Fly river. . . . Three varieties of stone club have been seen-the star, the " disc, and the pine-apple-but stone clubs are rare in a region where one may " travel for many miles without seeing a stone. A wooden club. usually of the pine" apple type, and made of very hard brown wood, is in more general use. The "drums are of decidedly original type, and on certain ceremonial occasions a drum " some $7 . \mathrm{ft} .[2 \cdot 135 \mathrm{~m}$.$] is used. This is held by one man, and heaten by a second$ " with a wooden mallet. The head of the drum is of wallaby skin."

Mr. Beaver gives four excellent photographs, one of men and women with their characteristic costume, one of the carved prow of a ceremonial canoe, one of a veiled woman standing by a large fish trap, and one of a man wearing a large mask of the type described by me; he is wearing a fringe petticoat, and holds in his hands a drum of the characteristic Tugeri (or Bugi) type (cf. Journ. Roy. Anthr. Inst., XLVI, p. 351). It is unfortunate that Mr. Bearer does not inform us whether this particular drum was really used by a "Girara" native - one constantly comes across photographs in which a person is holding an implement which is not strictly appropriate. $\mathrm{He}$ also gives a map of the district.

A. C. HADDON.

\section{India : Linguistics.}

\section{REVIEWS.}

Rudimentary Grammar of the Sema Naga Language, with Vocabulary. By

J. H. Hutton, I.C.S., Assistant Commissioner, Mokukchung. Shillong : Printed at the Assam Secretariat Printing Oflice. 1916.

This book gives a convenient summary of the grammar, and a useful vocabulary of the language spoken by the Sema people, one of the central tribes of the Western Nagas in Assam. (Cf. Map in MAN, 1917, 74.) The language of the present work differs somewhat from that shown in the Linguistic Survey of India (Vol. III, Pt. 3, p. 222 ff.), which is said by Mr. Hutton to be apparently that of the Lozemi and the Sema in the Dayang Valley, whilst the present volume represents that spoken by the Zümomi and the Sema of the Upper Kaliki River. 